\title{
HUBUNGAN DURASI BERMAIN VIDIO GAME DENGAN KETAJAMAN PENGLIHATAN PADA ANAK SEKOLAH DI SDN 007 PULAU BIRANDANG
}

\author{
Rinda Fithriyana \\ Program Studi DIII Kebidanan Universitas Pahlawan Tuanku Tambusai \\ rindaup@gmail.com
}

\begin{abstract}
Abstrak
Penglihatan adalah salah satu faktor yang sangat penting dalam seluruh aspek kehidupan termasuk diantaranya pada proses pendidikan. Meskipun fungsinya bagi kehidupan manusia sangat penting, namun sering kali kesehatan mata kurang terperhatikan, sehingga banyak penyakit yang menyerang mata tidak diobati dengan baik dan menyebabkan gangguan penglihatan. Pada tahun 2013 prevalensi gangguan ketajaman penglihatan pada anak usia sekolah di Indonesia meningkat yang disebabkan oleh aktivitas di depan layar kaca media elektronik seperti bermain video games. Tujuan penelitian ini adalah untuk mengetahui hubungan durasi bermain video games dengan ketajaman penglihatan pada anak sekolah di SDN 007 Pulau Birandang Tahun 2017. Desain penelitian ini adalah analitik dengan rancangan cross sectional. Populasi pada penelitian ini adalah seluruh siswa kelas V dan VI SDN 007 Pulau Birandang yang berjumlah 85 orang, menggunakan teknik pengambilan sampel dengan total sampling. Hasil penelitian diperoleh bahwa sebagian besar responden bermain video games $>2$ jam $(60 \%)$, sebagian besar responden penglihatannya tidak normal yaitu sebanyak 44 orang $(51,8 \%)$. Hasil penelitian didapatkan bahwa ada hubungan durasi bermain video games dengan ketajaman penglihatan pada anak sekolah di SDN 007 Pulau Birandang Tahun 2017. Diharapkan pihak sekolah dapat membuat program baru berupa ekstrakurikuler yang dibuat semenarik mungkin untuk mengalihkan kegiatan siswa dari bermain video game.
\end{abstract}

Kata Kunci: Durasi, Bermain, Vidio Games, Ketajaman Penglihatan

\begin{abstract}
Vision is one of the most important factors in all aspects of life including in the educational process. Although its function for human life is very important, but often eye health is less noticed, so many diseases that attack the eye are not treated properly and cause vision problems. In 2013 the prevalence of visual acuity disorders in school-age children in Indonesia increased due to activities in front of the electronic media screen such as playing video games. The purpose of this study was to determine the relationship of the duration of playing video games with visual acuity in school children at SDN 007 Birandang Island in 2017. The design of this study was analytic with cross sectional design. The population in this study were all students in grade V and VI SDN 007 Birandang Island, amounting to 85 people, using a sampling technique with total sampling. The results showed that the majority of respondents played video games $>2$ hours (60\%), the majority of respondents had abnormal vision as many as 44 people (51.8\%). The results showed that there is a relationship between the duration of playing video games with visual acuity in school children at SDN 007 Birandang Island in 2017. It is hoped that the school can create a new program in the form of extracurricular activities that are made as attractive as possible to divert student activities from playing video games.
\end{abstract}

Keywords: Duration, Playing, Video Games, Vision Sharpness

@ Jurnal Ners Prodi Sarjana Keperawatan \& Profesi Ners FIK UP 2019

$\triangle$ Corresponding author :

Address : Jl. Tuanku Tambusai No. 23 Bangkinang

Email : rindaup@gmail.com

Phone : 08127589128 


\section{PENDAHULUAN}

Penglihatan adalah salah satu faktor yang sangat penting dalam seluruh aspek kehidupan termasuk diantaranya pada proses pendidikan. Penglihatan juga merupakan jalur informasi utama, oleh karena itu keterlambatan melakukan koreksi terutama pada anak usia sekolah akan sangat mempengaruhi kemampuan menyerap materi pembelajaran dan berkurangnya potensi untuk meningkatkan kecerdasan. Meskipun fungsinya bagi kehidupan manusia sangat penting, namun sering kali kesehatan mata kurang terperhatikan, sehingga banyak penyakit yang menyerang mata tidak diobati dengan baik dan menyebabkan gangguan penglihatan atau kelainan refraksi (Depkes RI, 2009).

Kelainan refraksi yang tidak terkoreksi merupakan penyebab utama low vision di dunia dan dapat menyebabkan kebutaan. Data dari VISION 2020, suatu program kerjasama antara International Agency for the Prevention of Blindness (IAPB) dan WHO, menurut IAPB dan WHO pada tahun 2016 diperkirakan 153 juta penduduk dunia mengalami gangguan visus akibat kelainan refraksi yang tidak terkoreksi. Dari 153 juta orang tersebut, sedikitnya 13 juta diantaranya adalah anak-anak usia 5-15 tahun dimana prevalensi tertinggi terjadi di Asia Tenggara (WHO, 2012).

Gangguan penglihatan merupakan masalah kesehatan yang penting, terutama pada anak, mengingat $80 \%$ informasi selama 12 tahun pertama kehidupan anak didapatkan melalui penglihatan (Ester, 2013). Pada tahun 2013 prevalensi gangguan ketajaman penglihatan pada anak usia sekolah di Indonesia seperti di Jawa Barat sebanyak 0,8\%. Prevalensi visus lebih banyak pada anak yang ada di daerah pedesaan daripada perkotaan, hal tersebut ditunjukkan berdasarkan data Riskesdas tahun 2013 di mana proporsi visus pada anak usia sekolah di perkotaan sebesar $0,8 \%$ sedangkan di pedesaan sebesar $1,1 \%$ digunakan untuk melakukan screen-based activities atau aktivitas di depan layar kaca media elektronik tanpa melakukan aktifitas olahraga misalnya duduk menonton televisi atau video, bermain komputer, maupun bermain permainan video game (Fatma, 2013).

Saat ini masih tampak kurangnya perhatian di beberapa daerah di Indonesia mengenai masalah kelainan refraksi khususnya pada anak. Hal ini terbukti dengan adanya program pemeriksaan kesehatan anak sekolah dasar yang lebih difokuskan pada kesehatan gigi dan mulut, padahal lingkungan sekolah menjadi salah satu pemicu terjadinya penurunan ketajaman penglihatan pada anak, seperti membaca tulisan di papan tulis dengan jarak yang terlalu jauh tanpa didukung oleh pencahayaan kelas yang memadai, anak membaca buku dengan jarak yang terlalu dekat, dan sarana prasarana sekolah yang tidak ergonomis saat proses belajar mengajar (Wati, 2010).

Keterlambatan melakukan koreksi refraksi terutama pada anak usia sekolah akan sangat mempengaruhi kemampuan menyerap materi pembelajaran dan berkurangnya potensi untuk meningkatkan kecerdasan karena $30 \%$ informasi diserap dengan melihat dan mendengar (Wati, 2010).

Anak usia sekolah adalah investasi bangsa, karena mereka adalah generasi penerus bangsa. Kualitas bangsa dimasa depan ditentukan oleh kualitas anak-anak saat ini. Upaya peningkatan kualitas sumber daya manusia harus dilakukan sejak dini, sistematis dan berkesinambungan (Widodo, 2013).

Pada masa sekolah anak memasuki masa belajar didalam dan diluar sekolah. Banyak aspek perilaku dibentuk melalui penguatan (reinforcement) verbal, keteladanan dan identitas. Anak-anak pada masa ini harus menjalani tugastugas perkembangan salah satunya adalah belajar keterampilan untuk bermain. Dalam perkembangan ini anak tetap memerlukan penambahan pengetahuan melalui belajar (Gunarsa, 2011).

Bermain adalah unsur yang penting untuk perkembangan anak baik fisik, emosi, mental, intelektual, kreativitas, dan sosial. Anak usia sekolah adalah usia berkelompok atau sering disebut sebagai usia penyesuaian diri. Pada masa perkembangan anak usia sekolah, permainan yang paling diminati adalah permainan yang bersifat persaingan. Anak-anak masa sekolah mengembangkan kemampuan melakukan permainan dengan peraturan (Desmita, 2010).

Seiring dengan pesatnya perkembangan teknologi internet, game online juga mengalami perkembangan yang pesat. Game online adalah game yang berbasis elektronik dan visual. Game online dimasa sekarang begitu populer di berbagai kalangan, salah satunya populer diantara anak sekolah (Rini, 2011). 
Rini (2011) menjelaskan bahwa kerusakan mata pada anak usia sekolah salah satunya disebakan oleh pengaruh buruk vidio game pada anak. seperti berpengaruh terhadap kesehatan, kepribadian, pendidikan atau prestasi, serta terhadap keluarga dan masyarakat. Seorang anak yang memiliki kebiasaan bermain game, beresiko mengalami stres, kerusakan mata, pola tidur yang terganggu dan maag. Pada perkembangan kepribadiannya, anak bisa menjadi agresif hingga melakukan tindakan kekerasan dalam hubungannya dengan keluarga atau masyarakat. Sedangkan dalam pendidikannya, anak yang suka bermain game online memiliki masalah konsentrasi saat menerima pelajaran.

Pada era globalisasi ini, berjuta-juta permainan telah dibuat dengan teknologi yang semakin canggih. Semua orang dapat mengakses berbagai macam permainan melalui jaringan internet yang sering disebut game online. Game online tentunya dimainkan melalui media komputer. Dewasa ini, anak telah dikenalkan dengan teknologi sejak dini, sehingga mereka cukup mendominasi sebagai konsumen game online. Karena permainan merupakan dilakukan untuk memperoleh kesenangan maka hal ini dapat menjadi suatu kebiasaan. Hal tersebut dapat berarti bahwa kebiasaan bermain game online mengharuskan anak berlama-lama berkontak mata di depan layar komputer yang tentu akan berdampak pada kesehatan matanya (Dewi, M. 2011).

Anak-anak yang terus bermain video game selama berjam-jam akan berisiko menyebabkan masalah mata seperti sakit kepala, penglihatan kabur, susah melihat objek yang jauh, dan sering menyipitkan mata ketika melihat obyek jauh dan ketidaknyamanan di mata. Biasanya dialami anakanak usia 4 sampai 15 tahun yang sangat rentan menderita myopia atau rabun jauh

(Erin, 2012).

Gejala keluhan kelelahan mata ditandai dengan mata merah, berair, perih, gatal/kering, mengantuk, tegang, pandangan kabur, penglihatan rangkap, sakit kepala, dan kesulitan fokus. Rangkaian keluhan yang di awali dengan adanya keluhan kelelahan mata tersebut sering di sebut dengan Computer Visuon Syndrome (CVS) (Erin, 2012).

Dalam Faizah (2008), CVS dapat di akibatkan karena berkurangnya aliran air mata ke mata atau disebabkan oleh terlalu besarnya refleksi maupun silau dari monitor. Saat menatap layar monitor bermain game online, maka kedipan mata berkurang sebesar 2/3 kali dibandingkan kondisi normal, yang mengakibatkan mata menjadi kering, teriritasi, tegang, dan lelah. Pencahayaan komputer yang tidak tepat juga mengakibatkan gangguan mata seperti ketegangan dan kelelahan pada mata.

Gangguan mata disebabkan karena gelombanggelombang pada layar monitor yang yang terlalu lama dilihat dapat maka sinar-X, Sinar ultraviolet, Gelombang mikro (microwave), Radiasi elektromagnetik frekuensi sangat rendah (Very Low Frequency / VLF) dan Radiasi elektromagnetik frekuensi amat sangat rendah (Extremely Low Freqierncy / Elf) tersebut akan ditangkap oleh kornea mata, selanjutnya cahaya tersebut diteruskan ke lensa, lensa tersebut dapat rusak khususnya lensa mata pada anak usia sekolah karena secara fisiologis saraf mata anak masih rentan kerusakan akibatnya tajam penglihatan menurun. Penurunan ketajaman penglihatan tersebut tergantung dari lamanya durasi paparan dengan layar monitor sehingga pada saat bermain video game dianjurkan untuk tidak melebihi 2 jam setiap harinya (Pravita, 2010).

Pada anak usia sekolah yang gemar bermain video game dengan durasi yang cukup lama, maka otot siliaris akan selalu mempengaruhi lensa menjadi cembung karena selalu melihat benda dekat sehingga kurang peka terhadap benda jauh, hal tersebut yang menyebabkan terjadinya gangguan ketajaman penglihatan sehingga alat ukur yang tepat menggunakan snellen chart (James, 2006). Penelitian Widyastari (2012) tentang hubungan riwayat pengoperasian komputer dengan ketajaman penglihatan, hasil penelitian diperoleh bahwa terdapat hubungan antara riwayat pengoperasian komputer dengan ketajaman penglihatan $(\mathrm{P}$ value $=0,007)$. Hal tersebut diperkuat oleh penelitian yang dilakukan oleh Lely (2009) dengan faktor-faktor yang berhubungan dengan ketajaman penglihatan pada siswa SDN 005 Tanah Datar, diperoleh bahwa faktor screen time (durasi) bermain video game lebih dari 2 jam per hari memiliki hubungan yang signifikan dengan ketajaman penglihatan $(\mathrm{P}$ value $=0,025)$.

Berdasarkan perbandingan pada tiga sekolah di Desa Pulau Birandang yaitu SDN 001, SDN 005 dan SDN 007 di Desa Pulau Birandang, didapatkan bahwa SDN 007 Pulau Birandang merupakan salah satu sekolah yang terdapat di Kecamatan Kampar Timur yang memiliki jumlah 
murid terbanyak yaitu 240 siswa. Studi pendahuluan yang dilakukan oleh peneliti kelas $\mathrm{V}$ SDN 007 Pulau Birandang ditemukan 4 orang siswa yang telah menggunakan kacamata dan hasil wawancara terhadap 10 siswa diperoleh bahwa 7 siswa mengalami berbagai keluhan mata seperti mata sering berair, mata merah, perih dan mata sering merasa lelah dimana ke sepuluh siswa tersebut rata-rata bermain video game selama 2,5 jam perhari dengan frekuensi bermain 3 kali dalam sehari dan hal ini berdampak pada penurunan proses belajar.

Berdasarkan wawancara terhadap guru di SDN 007 Pulau Birandang, mereka mengatakan bahwa selama ini belum ada petugas kesehatan dari Puskesmas atau Rumah Sakit yang memberikan penyuluhan tentang bahaya bemain game pada anak sekolah dan pengukuran ketajaman penglihatan dengan menggunakan Snellen chart.

Berdasarkan latar belakang diatas, maka peneliti tertarik untuk melakukan penelitian dengan judul hubungan durasi bermain video game dengan ketajaman penglihatan pada anak sekolah di SDN 007 Pulau Birandang tahun 2017.

\section{METODE}

\section{Desain Penelitian}

Desain penelitian ini adalah analitik dengan rancangan cross sectional (potong lintang), yaitu setiap variabel diobservasi hanya satu kali saja dan pengukuran masing-masing variabel dilakukan pada waktu yang sama (Notoatmodjo, 2010). Penelitian ini menggunakan jenis penelitian korelasional karena bertujuan untuk menjelaskan hubungan antara durasi bermain video game dengan ketajaman penglihatan pada anak sekolah di SDN 007 Pulau Birandang.

\section{Lokasi dan Waktu Penelitian}

Penelitian ini dilaksanakan di SDN 007 Pulau Birandang pada tanggal 10 - 12 Juli 2017.

\section{Populasi}

Populasi adalah keseluruhan subjek penelitian (Notoatmodjo, 2010). Populasi pada penelitian ini adalah seluruh siswa kelas V dan VI SDN 007 Pulau Birandang yang berjumlah 85 orang.

\section{Sampel}

Sampel adalah sebagian objek yang diambil dari keseluruhan objek yang diteliti yang dianggap mewakili seluruh populasi (Hidayat, 2014). Yang menjadi sampel dalam penelitian ini adalah seluruh siswa kelas V dan VI SDN 007 Pulau Birandang dengan kriteria inklusi yaitu : siswasiswi kelas V dan VI di SDN 001 Pulau Birandang, memahami bahasa indonesia dan dapat membaca serta menulis. Sedangkan kriteria eksklusinya yaitu : anak dalam kondisi sakit, anak tidak ada disekolah pada saat penelitian, pada saat penelitian anak pindah, tidak bersedia menjadi responden.

Adapun teknik pengambilan sampel yang digunakan pada penelitian ini menggunakan total sampling, dimana semua populasi dijadikan sampel. Jadi Jumlah sampel yang diambil dalam penelitian ini sesuai dengan jumlah populasi yaitu 85 orang.

\section{Alat Pengumpulan Data}

Alat pengumpulan data yang digunakan dalam penelitian ini adalah kuesioner. Adapun bentuk pertanyaan yang berkaitan dengan durasi bermain vidio games berjumlah 1 pertanyaan dan ketajaman penglihatan dilakukan dengan Snellen chart.

\section{Analisa Data}

Analisa yang digunakan adalah analisa univariat dan analisa bivariat. Analisis univariat adalah analisa yang dilakukan terhadap tiap variabel dari hasil penelitian, analisis ini menghasilkan distribusi dan persentase dari tiap variabel (Notoatmodjo, 2010). Analisis ini bermanfaat untuk memberi gambaran karakteristik subyek penelitian dengan menghitung distribusi frekuensi dan proporsi. Analisa bivariat digunakan untuk meliihat hubungan antara variabel independen dengan variabel dependen. Analisa bivariat akan menggunakan uji Chi-Square $\left(\mathrm{X}^{2}\right)$ dengan menggunakan tingkat kepercayaan $95 \%$.

\section{HASIL DAN PEMBAHASAN}

Penelitian ini bertujuan untuk mengetahui hubungan durasi bermain video games dengan ketajaman penglihatan pada anak sekolah di SDN 007 Pulau Birandang tahun 2017. Penelitian ini dilakukan pada tanggal 10-12 Juli 2017 dengan jumlah sampel sebanyak 85 responden. Dari hasil pengumpulan data disajikan sebagai berikut: 
Analisis Univariat

Tabel 1: Distribusi Frekuensi Karakteristik Resonden Berdasarkan Umur di SDN 007 Pulau Birandang tahun 2017

\begin{tabular}{rlcc}
\hline No & $\begin{array}{c}\text { Umur } \\
\text { (Tahun) }\end{array}$ & Frekuensi & Persentase (\%) \\
\hline 1 & 11 Tahun & 31 & 36,5 \\
$\mathbf{2}$ & 12 Tahun & $\mathbf{4 8}$ & $\mathbf{5 6 , 5}$ \\
3 & 13 Tahun & 6 & 7,0 \\
\hline & Jumlah & $\mathbf{8 5}$ & $\mathbf{1 0 0}$
\end{tabular}

Berdasarkan tabel 1 dapat dilihat bahwa sebagian besar responden berada dalam kategori umur 12 tahun yaitu sebanyak 48 orang $(56,5 \%)$.

Tabel 2 : Distribusi Frekuensi Durasi Bermain Vidio Games di SDN 007 Pulau Birandang tahun 2017

\begin{tabular}{cccc}
\hline No & $\begin{array}{c}\text { Durasi Bermain } \\
\text { Vidio Games }\end{array}$ & Frekuensi & $\begin{array}{c}\text { Persentase } \\
(\boldsymbol{\%})\end{array}$ \\
\hline 1 & $<2$ jam/hari & 34 & 40,0 \\
$\mathbf{2}$ & $\geq \mathbf{2}$ jam/hari & $\mathbf{5 1}$ & $\mathbf{6 0 , 0}$ \\
\hline & Jumlah & $\mathbf{8 5}$ & $\mathbf{1 0 0}$ \\
\hline
\end{tabular}

Berdasarkan tabel 2 dapat diketahui bahwa sebagian besar responden bermain video games $\geq$ 2 jam/hari yaitu sebanyak 51 orang $(60 \%)$.

Tabel 3 : Distribusi Frekuensi Ketajaman Penglihatan di SDN 007 Pulau Birandang tahun 2017

\begin{tabular}{lccc}
\hline No & $\begin{array}{c}\text { Ketajaman } \\
\text { Penglihatan }\end{array}$ & Frekuensi & $\begin{array}{c}\text { Persentase } \\
(\mathbf{\%})\end{array}$ \\
\hline 1 Normal & 41 & 48,2 \\
2 Tidak Normal & $\mathbf{4 4}$ & $\mathbf{5 1 , 8}$ \\
\hline Jumlah & $\mathbf{8 5}$ & $\mathbf{1 0 0}$ \\
\hline
\end{tabular}

Berdasarkan tabel 3 dapat diketahui bahwa sebagian besar responden memiliki ketajaman penglihatan tidak normal yaitu sebanyak 44 orang $(51,8 \%)$.

\section{Analisa Bivariat}

Analisa bivariat ini menggambaran hubungan durasi bermain video games dengan ketajaman penglihatan pada anak sekolah di SDN 007 Pulau Birandang tahun 2017. Hasil analisis disajikan pada tabel berikut:

Tabel 4: Hubungan Durasi Bermain Video Games Dengan Ketajaman Penglihatan Pada Anak Sekolah Di SDN 007 Pulau Birandang Tahun 2017

\begin{tabular}{|c|c|c|c|c|c|c|c|}
\hline \multirow{3}{*}{$\begin{array}{l}\text { Durasi } \\
\text { bermain } \\
\text { video games }\end{array}$} & \multicolumn{4}{|c|}{ Ketajaman Penglihatan } & \multicolumn{2}{|c|}{ Total } & \multirow{3}{*}{$P$ value } \\
\hline & \multicolumn{2}{|c|}{$\begin{array}{c}\text { Tidak } \\
\text { normal }\end{array}$} & \multicolumn{2}{|c|}{ Normal } & & & \\
\hline & $\mathrm{n}$ & $\%$ & $\mathrm{n}$ & $\%$ & $\mathrm{n}$ & $\%$ & \\
\hline$\geq 2 \mathrm{Jam} / \mathrm{hari}$ & 32 & 67,2 & 19 & 37,3 & 51 & 100 & \\
\hline$\overline{<} 2$ jam/hari & 12 & 35,3 & 22 & 64,7 & 34 & 100 & 0,024 \\
\hline Jumlah & 44 & 51,8 & 41 & 48,2 & 85 & 100 & \\
\hline
\end{tabular}

Berdasarkan tabel 4 dapat dilihat bahwa dari 51 anak siswa yang durasi bermain video games $\geq 2$ jam/hari, terdapat 19 siswa $(37,3 \%)$ yang ketajaman penglihatannya normal, sedangkan dari 34 siswa yang durasi bermain video games $<2$ jam/hari, terdapat 12 siswa $(35,3 \%)$ memiliki ketajaman penglihatan tidak normal Berdasarkan uji statistik diperoleh nilai $\mathrm{p}$ value $=0,024(\mathrm{p}<$ $0,05)$, dengan derajat kemaknaan $(\alpha=0,05)$. Ini berarti terdapat hubungan yang signifikan antara durasi bermain video games dengan ketajaman penglihatan pada anak sekolah di SDN 007 Pulau Birandang tahun 2017. Dari hasil penelitian diketahui nilai POR $=3,0$ hal ini berarti siswa yang durasi bermain video games > 2 jam/hari berpeluang 3 kali untuk memiliki gangguan ketajaman penglihatan.

\section{PEMBAHASAN}

Berdasarkan hasil penelitian dapat dilihat bahwa dari 51 anak siswa yang durasi bermain video games $\geq 2$ jam/hari, terdapat 19 siswa $(37,3 \%)$ yang ketajaman penglihatannya normal, sedangkan dari 34 siswa yang durasi bermain video games $<2$ jam/hari, terdapat 12 siswa $(35,3 \%)$ memiliki ketajaman penglihatan tidak normal Berdasarkan uji statistik diperoleh nilai $\mathrm{p}$ value $=0,024 \quad(\mathrm{p}<0,05)$, dengan derajat kemaknaan $(\alpha=0,05)$. Ini berarti terdapat hubungan yang signifikan antara durasi bermain video games dengan ketajaman penglihatan pada anak sekolah di SDN 007 Pulau Birandang tahun 2017.

Menurut asumsi peneliti banyaknya siswa yang meliliki durasi bermain video games $\geq 2$ jam/hari disebabkan karena faktor lingkungan dan pengaruh teman sebaya yang selalu membawa anak pada kebiasaan yang buruk seperti seringnya anak pergi ke tempat warnet untuk bermain video games hingga larut malam yang akan mengakibatkan gangguan pola tidur anak, hal ini mengakibatkan radiasi cahaya berlebihan yang diterima oleh mata yang mengakibatkan gangguan ketajaman penglihatan pada siswa, sedangkan siswa yang bermain video games $\geq 2 \mathrm{jam} / \mathrm{hari}$ tetapi tidak mengalami gangguan penglihatan disebabkan karena anak sering mengkonsumsi sayur-sayuran dan sumber vitamin A yang dapat meyehatkan mata sehingga gizi yang dibutuhkan dalam tubuh Poterpenuhi. Anak yang bermain video games, < 2 jam/hari tetapi mengalami gangguan penglihatan 3, disebabkan karena adanya faktor genetik dari orang tua yang juga berefek kepada anaknya. Sedangkan responden yang durasi bermain video 
games > 2 jam menyebabkan gangguan penglihatan disebabkan karena kelelahan mata akibat terlalu lama di depan komputer dan gelombang elektromagnetik yang dihasilkan monitor komputer dapat mengganggu kesehatan mata.

Menurut Rifhani (2010), Kebiasaan bermain game online lebih dari 2 jam perhari secara otomatis akan menyebabkan pengguna berlamalama melakukan kontak mata langsung dengan layar komputer, tampilan layar monitor yang terlalu terang dengan warna yang panas seperti warna merah, kuning, ungu, oranye akan lebih mempercepat kelelahan pada mata. Pemakaian layar monitor yang tidak ergonomis dapat menyebabkan keluhan pada mata.

Sedangkan menurut Rahmat (2014) proses durasi mempengaruhi ketajaman penglihatan menurut Pravita (2010) yaitu disebabkan karena gelombang - gelombang pada layar monitor yang terlalu lama dilihat dapat maka sinar - X, Sinar ultraviolet, Gelombang mikro (microwave), Radiasi elektromagnetik frekuensi sangat rendah (Very Low Frequency / VLF) dan Radiasi elektromagnetik frekuensi amat sangat rendah (Extremely Low Freqierncy / Elf) tersebut akan ditangkap oleh kornea mata, selanjutnya cahaya tersebut diteruskan ke lensa, lensa tersebut dapat rusak khususnya lensa mata pada anak usia sekolah karena secara fisiologis saraf mata anak masih rentan kerusakan akibatnya tajam penglihatan menurun.

Efek vidio games pada mata sangat berbahaya. Sebab secara fisik, paparan cahaya radiasi komputer dapat merusak saraf mata. Saat asyik bermain game online, terkadang anak-anak lupa makan dan terus memaksakan matanya untuk menangkap sinyal gerak dalam layar komputer. Hal itu cenderung membuat mata lelah, namun tetap terbuka karena terpaksa. Pengaruh radiasi dari layar monitor adalah faktor utama yang bisa melelahkan mata. Terlebih jika didukung efek pencahayaan yang ditampilkan dalam sebuah game. Semakin terang radiasi cahaya monitor, mata akan semakin silau. Sebaliknya, semakin gelap cahayanya, dan mata juga akan tetap berusaha menangkap gerak cahaya itu. Dalam satu kali penglihatan, efek cahaya yang bisa terjadi bisa mencapai ratusan. Ini biasanya menyebabkan perut mual, jika kita terus memaksakan mata melihat TV atau monitor (Kuliksera, 2012).
Menurut Ester (2013) bahwa durasi yang dianjurkan anak dalam bermain video game yaitu tidak melebihi 2 jam setiap hari, hal tersebut karena bila terlalu lama terpapar layar monitor mata akan hilang fokus dan dalam jangka waktu cukup lama akan menyebabkan gangguan pada mata. Anak usia sekolah dasar banyak yang tertarik bermain video game karena menurut Hurlock (2012) bahwa tugas perkembangan anak usia sekolah diantaranya yaitu mempelajari ketrampilan fisik yang dipelukan untuk permainanpermaianan yang umum, belajar menyesuaikan diri dengan teman-teman seusianya, mengembangkan sikap terhadap kelompok-kelompok sosial dan lembaga-lembaga dan mencapai kebebasan pribadi. Pada tahap anak usia sekolah dasar (6-12 tahun) yaitu masuk pada tahap perkembangan industry vs inferiority, dimana dalam perkembangan ini anak akan belajar untuk bekerja sama dan bersaing dengan anak lainnya melalui kegiatan yang dilakukan baik dalam kegiatan akademik maupun dalam pergaulan melalui permainan yang dilakukan bersama.

Gangguan pada mata disebabkan adanya kejadian berulang yang menyebabkan bayangan tidak jatuh pada retina sehingga mengakibatkan seseorang mengalami penurunan ketajaman penglihatan. Apabila seseorang berada di tempat yang sangat terang untuk waktu yang lama, maka banyak sekali fotokimiawi yang terdapat didalam sel batang dan sel kerucut diubah menjadi retinal dan opsin. Selanjutnya sebagian besar retinal dalam sel batang dan sel kerucut akan banyak berkurang, akibatnya sensitivitas terhadap cahaya juga turut berkurang (Guyton \& Hall, 2006).

Efek game online pada mata sangat berbahaya. Sebab secara fisik, paparan cahaya radiasi komputer dapat merusak saraf mata. Saat asyik bermain game online, terkadang anak-anak lupa makan dan terus memaksakan matanya untuk menangkap sinyal gerak dalam layar komputer. Hal itu cenderung membuat mata lelah dan menyebabkan penurunan ketajaman pengelihatan, namun tetap terbuka karena terpaksa (Broto, 2008).

Menurut Syaifuddin (2014) efek bermain vidio games dalam waktu yan lama juga akan megakibatkan kualitas tidur anak akan terganggu, hal ini disebabkan karena waktu yang mereka gunakan untuk bermain video games dari siang, 
sore hingga larut malam yang akan berdampak pada kurangnya waktu tidur pada anak.

Menurut Widyastari (2012) dengan judul gambaran perubahan ketajaman penglihatan pada anak usia sekolah yang bermain game online di warnet X Kecamatan Ungaran Barat Kabupaten Semarang. diperoleh hasil bahwa rata-rata durasi bermain game online pada anak usia sekolah sebesar 20,80 jam per minggu dan rata-rata nilai visus mata anak menurun dengan nilai 0,8 sebanyak $35 \%$ dimana nilai normal visus yaitu $20 / 20$ atau 1,0

\section{SIMPULAN}

1. Sebagian besar responden bermain video games $\geq 2$ jam/hari yaitu sebanyak 51 orang $(60 \%)$.

2. Sebagian besar responden memiliki ketajaman penglihatan tidak normal yaitu sebanyak 44 orang $(51,8 \%)$.

3. Terdapat hubungan yang signifikan antara durasi bermain video games dengan ketajaman penglihatan pada anak sekolah di SDN 007 Pulau Birandang tahun 2017.

\section{SARAN}

1. Bagi Sekolah diharapkan dapat membuat program baru berupa ekstrakurikuler yang dibuat semenarik mungkin untuk mengalihkan kegiatan siswa dari bermain video game, serta melakukan pengawasan selama berada di lingkungan sekolah atau bila perlu memberi teguran pada siswa yang kedapatan bermain video game dengan melakukan kontrol ke lapangan secara berkala ke tempat-tempat penyewaan jasa video game serta mengadakan pendidikan kesehatan mengenai bahaya bermain video game.

2. Bagi penelitian selanjutnya yang ingin melakukan penelitian gangguan penglihatan pada anak, agar dapat menjadikan penelitian ini sebagai acuan dalam dalam penelitian selanjutnya dengan variable yang berbeda.

\section{DAFTAR PUSTAKA}

Broman. (2011). Dampak Video Game pada Anak Perlu Diwaspadai. Kolumnis: Rab A. Broto

Depkes. RI. (2009). Pedoman Pelaksanaan Stimulasi, Deteksi dan Intervensi Dini Tumbuh Kembang Anak di Tingkat Pelayanan Kesehatan Dasar Jakarta, Depkes RI; 2009.
Desmita. (2010). Psikologi Perkembangan. Bandung: Rosda

Dewi. (2011). Pengaruh Kebiasaan Anak dalam Bermain Game Online pada Komputer terhadap Kesehatan Mata. KTI : SMA Negeri 1 Jember.

Erin. (2012). Pengaruh Bermain Komputer Pada Kesehatan Mata Anak-Anak. Jakarta : Ilmu Penyakit Mata RS. Cipto Mangunkusumo.

Fatma. (2013). Faktor-Faktor Yang Berhubungan Dengan Keluhan Subjektif Kelelahan Mata Pada Pengguna Komputer Di Pt Bukit Asam (Persero)Tbk UPTE. (online). Dari http://fkmus.ac.id/indeks.php). Diakses 06 April 2017

Faizah. (2008). Game Online Sebuah Fenomena Budaya Pergaulan Baru. Jakarta: Acta Diurna

Gunara. (2011). Perkembangan Anak (6th Ed). Indonesia: Erlangga

Hidayat, A.A. (2011), Riset Keperawatan dan Teknik Penulisan Ilmiah, Jakarta : Salemba Medika

Ilyas. (2013). Kelainan refraksi dan koreksi penglihatan. Jakarta: Balai Penerbit FKUI.

James. (2006). Oftalmologi EMS Edisi Sembilan. Penerbit Erlangga Ciracas Jakarta.

Kartika. (2015. Adiksi Game Online Pada Remaja dan Cara Bijak Menyikapinya. Bandung. Erlangga

Lely. (2009). Faktor-Faktor Yang Berhubungan dengan Ketajaman Pada Pelajar Sekolah Dasar Katolik Santa Theresia 02 Kota. Jurnal Fakultas Kesehatan Masyarakat Universitas Sam Ratulangi Manado. Diakses 08 April 2017

Mahmudin. (2014). Hubungan Durasi Dan Frekuensi Bermain Video Game Dengan Masalah Mental emosional pada remaja. Jurnal. Program pendidikan sarjana kedokteran Fakultas kedokteran universitas diponegoro Semarang

Notoatmodjo, S. (2010). Metode Penelitian Kesehatan. Jakarta : Rineka Cipta.

Rini. (2011). Prevalensi Penurunan Ketajaman Penglihatan pada Siswa-siswi Sekolah Dasar Kelas 4-6 di Yayasan Pendidikan Shafiyyatul Amaliyyah Medan. Diakses 08 April 2017

Sabri. (2013). Hubungan Frekuensi Bermain Video Games dengan Tingkat Kematangan Sosial 
pada Anak. Departement of Psychology. Malang: UNIKOM

Wati. (2010). Hubungan Antara Aktivitas Fisik Dan Screen Time Dengan Status Gizi Pada Siswa-Siswa SMP Kristen Eben Haezar 2. (Tesis) : Universitas Sam Ratulangi Program Pasca Sarjana Program Studi IKM. Diakses 08 April 2017

Wahyuni. (2014). Ayo Ikut Sehari Bermain Bersama Anak Agar Terbebas dari Game Online. From http://antaranews.com, 03 April 2017

Widodo. (2013). Perilaku Perkembangan Anak Fakultas Psikologi, Universitas Gunadarma, Depok

Widyastari. (2012). Hubungan Riwayat Pengoperasian Komputer Dengan Ketajaman Penglihatan. Jakarta : Universitas Guna Dharma. Diakses tanggal 17 April 2017

Yutami. (2013). Faktor-Faktor yang Berhubungan dengan Keluhan Kelelahan Mata pada Pekerja Pengguna Komputer di Corporate Costumer Care Centre (C4) PT. Telekomunikasi Indonesia, Tbk Tahun 2009. Skripsi : Jakarta. UIN Syarif Hidayatulah. Diakses tanggal 10 April 2017 